AJHSE Vol: 1 (1): 22-37, 2020

Article Ref. No.: AJHSE-0101-07

Accepted Date: Jan. 24, 2020

(C) 2020. CC License 4.0

www.ajhse.org

CrossMark

$\leftarrow$ click for updates
African Journal of Health, Safety and Environment

An official publication of the

Applied Environmental Bioscience and Public Health Research Group University of Benin, Benin City, Nigeria Open Access | Bi-annual | Peer-reviewed | International ISSN (Online): 2695-1819 | ISSN (Print): 2695-2386

\title{
HEALTH RISKS ASSOCIATED WITH HEAVY METALS IN COMMERCIAL CHICKEN MEAT VIA CONSUMPTION WITHIN SOUTHERN NIGERIA
}

\author{
${ }^{* 1}$ Ogu, G. I. and ${ }^{2}$ Akinnibosun, F. I.
}

\author{
${ }^{*}$ Department of Biological Sciences, College of Natural and Applied Sciences, Novena University, Ogume, Delta State, Nigeria \\ *Phone: +234-7037605625; *Email: gideoniogu@gmail.com \\ ${ }^{2}$ Department of Microbiology, Faculty of Life Sciences, University of Benin, P.M.B. 1154, Benin City, Edo State, Nigeria \\ Phone: +234-8146247781; Email: fakinnibosun@yahoo.co.uk,faith.akinnibosun@uniben.edu
}

\begin{abstract}

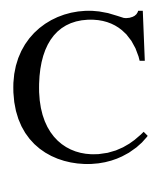

hicken meat is classed among one of the major sources of animal proteins and still enjoys global acceptance to date without recourse to their heavy metal residues. Hence, this study investigated the heavy metal residues in raw chicken meat and the associated health risk via consumption within major markets in southern Nigeria. A total of 240 raw chicken meat samples (muscle tissues) were purchased randomly from Warri, Akure, Ado-Ekiti and Benin City markets. After ashing, digestion and heavy metals analysis for $\mathrm{Pb}, \mathrm{Cr}, \mathrm{Cd}, \mathrm{Mn}, \mathrm{Ni}$, $\mathrm{Zn}$ and $\mathrm{Cu}$ using standard atomic adsorption spectrophotometer, the target hazard quotient (THQ), health risk index (HI) and daily intake index (non-carcinogenic risk) and incremental cancer risk in children and adults were determined. The mean heavy metals ranged from $0.001 \pm 0.001 \mathrm{mg} / \mathrm{kg}(\mathrm{Cr})$ to $2.094 \pm 0.001 \mathrm{mg} / \mathrm{kg}(\mathrm{Zn})$ and varied significantly $(\mathrm{P}<0.05)$ with Warri samples $(58.9 \%)$ yielding the highest level, followed by Benin City (26.8 \%), Ado-Ekiti (10.2 $\%)$ and Akure $(4.2 \%)$ samples. The non-carcinogenic risks (HR/HI) were substantially low for the metals studied in all the locations except for $\mathrm{Cd}$, which could pose serious health risk among children in Warri location. However, the incremental cancer risk ranged from $10^{-4}$ to $10^{-3}$ in all the locations, suggesting at least a cancer case per 1,000 exposed people (both in children and adults). Considering the impending public health risks, critical hazards points of heavy metals contaminations along meat production chains should be properly identified to drastically reduce their potential risks to exposed consumers.
\end{abstract}

Keywords: chicken meat, hazard ratio, health risk, heavy metals, incremental cancer risks

LICENSE: This article by African Journal of Health, Safety and Environment (AJHSE) is licensed and published under the Creative Commons Attribution License 4.0 International License, which permits unrestricted use, distribution, and reproduction in any medium, provided this article is duly cited.

COPYRIGHT: The Author(s) completely retain the copyright of this published article.

OPEN ACCESS: The Author(s) approves that this article remains permanently online in the open access (OA) mode.

QA: This Article is published in line with "COPE (Committee on Publication Ethics) and PIE (Publication Integrity \& Ethics)". 


\section{INTRODUCTION}

Plants are the primary sources of food to humans. Apart from plants, humans also derive a good portion of their foods from animals. Several animals serve as good sources nutrients, particularly proteins along with certain minerals, vitamins and trace metals, which are essential for healthy growth and development. Among these, poultry meats, particularly, chicken meat are most widely accepted over beef or pork in Nigeria due to their excellent source of proteins, high digestibility, taste, low fat/cholesterol, and without religious or health taboo (Javadi and Safarmashaei, 2011; Ogu et al., 2017).

One of the major health risks of challenges of poultry meat in developing countries is the potential exposure of these animals or their products to contamination with toxic metals during the feeding, transportation, processing or retailing stages (Ogu et al., 2017). Recent reports from prevent studies have highlighted the potentials of contamination of tissues and organs of chicken meat by heavy metals, globally (Benouadah et al., 2015; Haleelu et al., 2015; Makanjuola, 2016; Ogu et al., 2017; Mottalib et al., 2018). Intense pollution of the environment by human and industrial wastes such as over-reliance on agro-chemicals, chemical raw materials and fossil fuel combustion has been identified as common sources of heavy metals (Tchounwou et al., 2012; Jaishankar et al., 2014). From these sources, the metals find their way into raw and processed food of plants and animals' origins.

Although, some of these metals are essential for normal functioning of the organ-systems, they can become lethal when consumed in food above a threshold (Jaishankar et al., 2014). Others, such as cadmium $(\mathrm{Cd})$, lead $(\mathrm{Pb})$ and mercury ( $\mathrm{Hg}$ ) are classified as non-essential and highly toxic even at very low concentrations (Järup, 2003; Tchounwou et al., 2012). Exposure of humans to these heavy metals via consumption of contaminated products could lead to diverse chronic and acute health hazards. The toxicity of lead $(\mathrm{Pb})$ via food, water, or inhalation include kidney, livers, heart and brain tissues and nervous systems disorders leading to diverse nervous disorders and deformities especially in young children (Jaishankar et al., 2014; Salazar-Flores et al., 2019). Cadmium (Cd) cause fatal problems in the pulmonary and gastrointestinal tracts leading to severe injury in the pulmonary, hepatic, renal systems as well as gastrointestinal tract erosion and coma, depending on the routes and dose of the meta (Jaishankar et al., 2014). Nickel induces respiratory injury among other tissue toxicity (Jaishankar et al., 2014). Mercury exerts acute neurotoxity, kidney failure and gastrointestinal disorders (Salazar-Flores et al., 2019). At high concentrations in edible food, above the beneficial limits, Zinc $(\mathrm{Zn})$ and copper $(\mathrm{Cu})$ have been found to alter the normal physiology organs and systems (Suruchi and Pankaj Khanna, 2011; Jaishankar et al., 2014; Salazar-Flores et al., 2019).

In recent times, attentions of researchers have shifted to the investigation of health risks associated with the exposure to heavy metals in different food globally (Shaheen et al., 2016; Ekhator et al., 2017; Abdel-Rahman, et al., 2018; Elalfy et al., 2018; Issa et al., 2018; Hu et al., 2018; Kigigha et al., 2018; Kim et al., 2018; Thompson and Darwish, 2019). The increasing interest currently developed by researchers globally on the challenges of heavy metal contamination is borne out of the fact that heavy metals have been known to cause serious tissues and organ damages (Ogu et al., 2017). They are recalcitrant, and can readily accumulate in tissues of organisms thereby posing serious health risks along the food chain (Tchounwou et al., 2012; Jaishankar et al., 2014). Thus, continuous consumption of certain food products which are contaminated with such heavy metals could expose the consumers to their short and long-term detrimental effects. Therefore, it is pertinent to constantly monitor their levels in frequently consumed 
poultry product, such as chicken meat, in order to ascertain the potential health risks to consumers and the trend of environmental heavy metal pollution. Despite the relatively high cost of chicken meat and the ban on importation of frozen chicken in the country, majority of Nigerians still patronize chicken meat sold in groceries as well as road side open market without recourse to their chemical and biological wholeness (Makanjuola, 2016; Ogu et al., 2017; Ekhator et al., 2017; El-Wehedy et al., 2018; Ogu and Akinnibosun, 2019).

\section{Aim and Objectives}

This study was carried out to investigate the concentrations of some heavy metals in raw chicken meat sourced from major open markets in southern Nigeria and their possible public health risks via consumption.

\section{MATERIALS AND METHODS}

\section{Study location}

The study locations of this study include major open markets sited in the capital cities of selected Niger Delta State and environ. The study locations included four major open markets located in selected major capital cities in and around the Niger Delta region, namely, Effurun main market (Warri metropolis, Delta State), Oja-Oba market, Akure, Ondo State), Oba market (Benin City, Edo State), and Oja-Oba market (Ado-Ekiti, Ekiti State). The study areas were located in the South West (Ondo and Ekiti State) and South-South (Delta and Edo States) Nigeria (Figure 1)

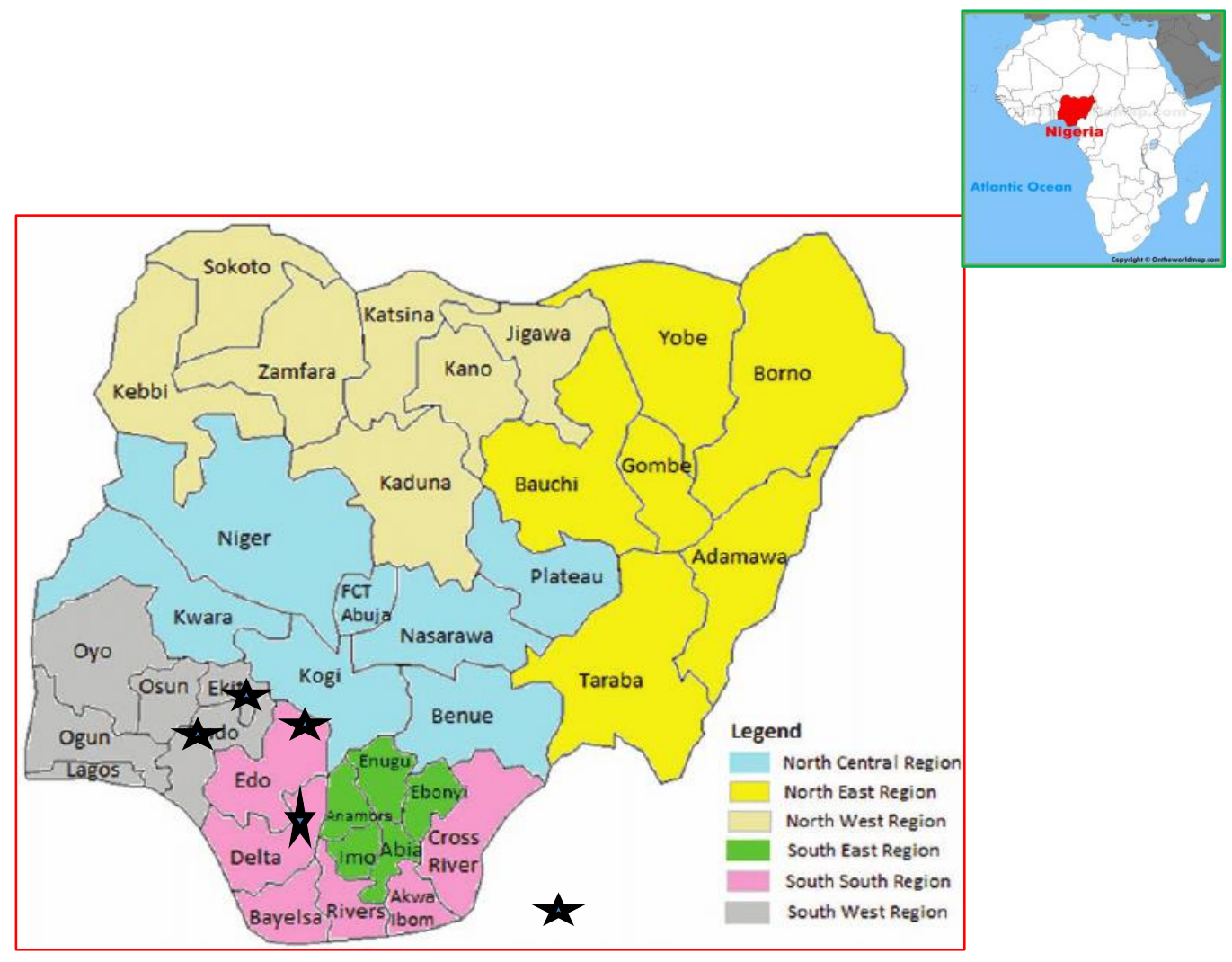

Figure 1. Map of Africa, showing Nigeria and the States

Source: Gayawan et al., 2014 


\section{SAMPLE COLLECTION}

A total of 240 samples, comprising 60 raw chicken meats samples (muscle tissues) from each study location, were randomly sourced, separately packaged in polyethene bags (previously washed with de-ionised water) and transported to the laboratory for pre-treatment and heavy metal analysis using standard techniques. The sampling regime was done quarterly from October 2017 to September, 2018.

\section{SAMPLE-PRE-TREATMENT}

The samples were washed using deionised water and oven dried at $40^{\circ} \mathrm{C}$ for 3-5 days, before pulverising using laboratory mortar and pestle

\section{SAMPLE DIGESTION AND METAL ANALYSIS}

A digestion mixture $\mathrm{HNO}_{3}, \mathrm{HClO}_{4}$ and $\mathrm{H}_{2} \mathrm{O}_{2}$ (10:1:2) was use to pulverise the pretreate samples as report earlier (Ogu, et al., 2017). Exactly $5.0 \mathrm{~mL}$ of the digestion mixture was withdrawn into the digestion tube containing $0.5 \mathrm{~g}$ each of the samples and allowed to digest at $150{ }^{\circ} \mathrm{C}$. To ensure complete digestion, another $5.0 \mathrm{~mL}$ of the digestion solution was added to the tube and gently heated until a clear soultion resulted. The solution was allowed to cooled before filtering the content into a $100 \mathrm{~mL}$ clean conical flask. The remaining volume was made up by adding distilled water. Blank set ups were carried out for quality control measures. The selected heavy metals ( $\mathrm{Pb}, \mathrm{Cr}, \mathrm{Cd}, \mathrm{Mn}, \mathrm{Ni}, \mathrm{Zn}$ and $\mathrm{Cu}$ ) were then determined using graphite furnace atomic absorption spectrophotometer (GBS Scientific Equipment SensAAS 1175, Australia. The residual concentrations of the each heavy metal determined was expressed as $\mathrm{mg} / \mathrm{kg}$ wet weight

\section{QUANTITATIVE HUMAN HEALTH RISK ANALYSIS}

The potential risks of exposure of humans to these heavy metals via consumption of contaminated chicken meat involves the determination of the including estimated daily intake (EDI), vis-a-vis the carcinogenic and noncarcinogenic effects by using the US EPA model and its threshold values as reported earlier (Ekhator et al., 2017; USEPA, 2018)

$$
\text { Estimated Daily Intake }(\text { EDI })=\frac{\mathrm{Cm} \times \mathrm{Df}}{\mathrm{Bwt}}
$$

Where:

$\mathrm{Cm}$ is the metal concentration in meat in $\mathrm{mg} / \mathrm{kg}$

Df intake is the daily intake of food (chicken meat) in kg per individual and

Bwt is average body weight in $\mathrm{kg}$ per individual.

Average daily consumptions of $46.59 \mathrm{~kg}$ (children) and $60.95 \mathrm{~kg}$ (adult) of the chicken meat was assumed in this study. These values were adopted because chicken meat constitute a major part of the diet of an average Nigerian and 
in relation to previous studies (Oforka et al., 2012; Ekhator et al., 2017; Patrick-Iwuanyanwu and Chioma, 2017). Average adult body weights were considered to be $70 \mathrm{~kg}$ (adults) and $24 \mathrm{~kg}$ (children) (Ekhator et al., 2017)

\section{DETERMINATION OF NON-CARCINOGENIC RISK:}

The risk of non-carcinogenic effects of heavy metal consumption in the meat was determined by using the formulae of Target Hazard Quotient (THQ) and Chronic Hazard Index (HI) (Mottalib et al., 2018; USEPA, 2018;)

THQ is a ratio of the determined dose of a toxicant to a reference dose considered harmful. If the ratio is equal to or greater than 1, an exposed population is at risk. THQ values were calculated using the following formula below (Patrick-Iwuanyanwu and Chioma, 2017; Mottalib et al., 2018; USEPA, 2018).

$$
\text { Target Hazard Quotient }(\mathrm{THQ})=\frac{E F \times E D \times I R \times C M}{B W A \times A T n \times R f D \times 1000}
$$

Where:

Where THQ is the target hazard quotient,

EF is the exposure frequency (365 days/year),

$\mathrm{ED}$ is the exposure duration (30 years for non-cancer risk as suggested by the USEPA),

IR is the ingestion rate of chicken tissue (g/individual/day),

$\mathrm{CM}$ is the metal concentration in chicken $(\mathrm{mg} / \mathrm{kg})$,

BWA is the average body weight,

ATn is the average exposure time for non-carcinogens (EF×ED) (365 days/year) for 30 years (ATn=10,950 days) as used for characterizing non-cancer risk, and

$\mathrm{RfD}$ is the reference oral dose of the metal (an estimate of the daily exposure to which the human population may be continuously exposed over a lifetime without an appreciable risk of deleterious effects ( $\mathrm{RfD}$ for $\mathrm{Cu}, \mathrm{Cd}, \mathrm{Pb}, \mathrm{Zn}, \mathrm{Cr}$, $\mathrm{Mn}, \mathrm{Ni}$ are $0.040,0.001,0.004,0.300,1.500,0.020$ and $0.140 \mathrm{mg} / \mathrm{kg}$ body weight per day respectively) (Adedokun et al., 2016; Patrick-Iwuanyanwu and Chioma, 2017 ; USEPA, 2018; Mottalib et al., 2018).

\footnotetext{
Hazard Index (HI) = THQ (Pb) + THQ (Cr) + THQ (Cd) + THQ (Cu) + THQ (Zn) + THQ (Ni) + THQ (Mn)--(3) Where:

$\mathrm{HI}=$ Chronic Hazard Index

THQ = Target hazard quotient for multiple metals or toxicants
}

\section{DETERMINATION OF CARCINOGENIC RISK}

This is also known as the target cancer risk analysis, which is the probability of an individual lifetime health risks from daily consumption of cancer-causing agents or metals in food (USEPA, 2018). The Incremental lifetime cancer risk (ILCR). ILCR is obtained using the Cancer Slope Factor (CSF) which evaluates the probability of an individual developing cancer from oral exposure to toxicant levels over a period of a lifetime and it is contaminant specific (Patrick-Iwuanyanwu and Chioma, 2017; USEPA, 2018). Ingestion cancer slope factors are expressed in units of ( $\mathrm{mg} / \mathrm{kg} /$ day). This was estimated using the formula: 
Where:

EDI is the estimated daily intake of each heavy metal ( $\mathrm{mg} / \mathrm{kg} / \mathrm{day})$

CPSo is the carcinogenic potency slope, oral (mg/kg body weight/day), are $0.0085,0.38,0.5,1.5$ and 1.7 for $\mathrm{Pb}, \mathrm{Cd}$, $\mathrm{Cr}, \mathrm{Cu}$ and $\mathrm{Ni}$, respectively (USEPA, 2018).

\section{STATISTICAL ANALYSIS}

Data generated were analysed and presented as means \pm standard errors (SE). One-way analysis of variance (ANOVA) (SPSS for Windows 21.0) was used to analysed the results and Duncan's test was used to compare the means with statistical level of significance set at $\mathrm{P}<0.05$.

\section{RESULTS AND DISCUSSION}

Chicken meat is classed among one of the major sources of animal proteins and still enjoys global acceptance to date. Previous studies have reported that poultry meat was exposed to xenobiotics during feeding, transportation, processing and or retailing stages (Ogu et al., 2017; Thompson and Darwish, 2019). In Nigeria, the general public still patronizes chicken meat (Fresh and frozen) retailed in groceries as well as road side open market without recourse to their biological and chemical wholesomeness. Generally, thorough thermal treatment of meat inactivates the microbial contaminants and relatively reduce their risk thereby. However, chemical risk is not readily arrested via same thermal treatment (El-Wehedy et al., 2018), hence the need for constant monitoring of commercial meat for their chemical residues, particularly, the heavy metal contents.

In this study, the heavy metal residue of commercial fresh chicken meat samples was investigated with a view to estimating the potential public health risk associated thereby via consumption. It was found that all the analysed samples contained varying levels of each metal $(\mathrm{Pb}, \mathrm{Cr}, \mathrm{Cd}, \mathrm{Mn}, \mathrm{Ni}, \mathrm{Zn}$ and $\mathrm{Cu})$ depending on the location as presented in Table 1. The level of $\mathrm{Pb}$ was highest in Ado-Ekiti chicken samples $(0.141 \pm 0.025 \mathrm{mg} / \mathrm{kg})$ and lowest in Akure chicken Samples $(0.0102 \pm 0.000 \mathrm{mg} / \mathrm{kg})$. Similarly, Cr was highest in Ado-Ekiti chicken samples $(0.078 \pm$ $0.057 \mathrm{mg} / \mathrm{kg})$ and lowest in Akure chicken Samples $(0.001 \pm 0.001 \mathrm{mg} / \mathrm{kg})$. Also, Cd was highest in Ado-Ekiti chicken samples $(0.323 \pm 0.022 \mathrm{mg} / \mathrm{kg})$ and lowest in Akure chicken Samples $(0.005 \pm 0.000 \mathrm{mg} / \mathrm{kg})$.

However, Mn was highest in Warri samples $(1.206 \pm 0.003 \mu \mathrm{g} / \mathrm{g})$ and lowest in Ado-Ekiti samples $(0.100 \pm$ $0.001 \mathrm{mg} / \mathrm{kg})$. Also, Ni was highest in Warri samples $(1.981 \pm 0.002 \mathrm{mg} / \mathrm{kg})$ and lowest in Akure samples $(0.099 \pm$ $0.002 \mathrm{mg} / \mathrm{kg}$ ). Similarly, Zn was highest in Warri samples $(2.094 \pm 0.001 \mathrm{mg} / \mathrm{kg})$ and lowest in Akure samples $(0.089$ $\pm 0.013 \mathrm{mg} / \mathrm{kg})$. Finally, $\mathrm{Cu}$ was highest in Warri samples $(0.192 \pm 0.120 \mathrm{mg} / \mathrm{kg})$ and lowest in Akure samples $(0.067$ $\pm 0.001 \mathrm{mg} / \mathrm{kg})$. In generally, $\mathrm{Pb}, \mathrm{Cr}$ and $\mathrm{Cd}$ were highest in Ado-Ekiti chicken samples $(0.078 \pm 0.057 \mathrm{mg} / \mathrm{kg}-0.323$ $\pm 0.022 \mathrm{mg} / \mathrm{kg})$, while $\mathrm{Mn}, \mathrm{Ni}, \mathrm{Zn}$ and $\mathrm{Cu}$ were highest in Warri chicken samples $(0.192 \pm 0.120 \mathrm{mg} / \mathrm{kg}-2.094 \pm$ $0.001 \mathrm{mg} / \mathrm{kg})$.

When compared with previous studies on heavy metal residues in raw meat samples, the concentration of the heavy metals recorded in this study were lower than those reported by El-Wehedy et al. (2018) for $\mathrm{Pb}(0.248 \pm 0.073$ 
$\mathrm{mg} / \mathrm{kg}), \mathrm{Cd}(0.114 \pm 0.054 \mathrm{mg} / \mathrm{kg})$ and $\mathrm{Cu}(1.629 \pm 0.166 \mathrm{mg} / \mathrm{kg})$ for raw chicken meats sold at Hospitals in Egypt. Similarly, higher levels of $\mathrm{Cu}, \mathrm{Zn}, \mathrm{Pb}$, and $\mathrm{Cd}$ were found in poultry meat retailed in Sharkia Governorate, Egypt (ElBayomi et al., 2019). Also, substantially higher ranges of $\mathrm{Pb}, \mathrm{Cd}, \mathrm{Ni}, \mathrm{Cu}$ and $\mathrm{Cr}$ in chicken meat were reported from Bangladesh (Mottalib et al., 2018), China (Wang et al., 2018), Algeria, (Benouadah et al., 2015).

However, the concentrations of heavy metals in this study were substantially lower than highest concentrations reported for $\mathrm{Cu}(0.01-5.15 \mathrm{mg} / \mathrm{kg}), \mathrm{Zn}(4.95-48.23 \mathrm{mg} / \mathrm{kg}), \mathrm{Ni}(0.13-7.93 \mathrm{mg} / \mathrm{kg}), \mathrm{Mn}(0.01-1.37$ $\mathrm{mg} / \mathrm{kg}$ ), $\mathrm{Cd}(0.01-5.68 \mathrm{mg} / \mathrm{kg}), \mathrm{Pb}(0.01-4.60 \mathrm{mg} / \mathrm{kg}$ ) and $\mathrm{Cr}(0.01-3.43)$ (Iwegbue et al., 2008). Our findings are also in agreement with the work of Makanjuola (2016), who reported $\mathrm{Cu}(0.55-1.22 \mathrm{mg} / \mathrm{kg}), \mathrm{Ni}(0.01-0.56 \mathrm{mg} / \mathrm{kg})$, $\mathrm{Mn}(1.27-1.42 \mathrm{mg} / \mathrm{kg}), \mathrm{Pb}(0.01-0.02 \mathrm{mg} / \mathrm{kg}), \mathrm{Cd}(0.01 \mathrm{mg} / \mathrm{kg})$ from different meat retailed in some notable Garages within Ogun State, South West, Nigeria. Comparable results were reported by Odoh et al. (2016) for these heavy metals profiles in meat of domesticated animals within the vicinity of Kaduna South industrial area of Nigeria. Our findings were also in consonance with the report from Algeria (Benouadah et al., 2015) excluding $\mathrm{Cd}$ and $\mathrm{Pb}$, which varied substantially. Olusola et al. (2012) reported higher levels of $\mathrm{Pb}$ and $\mathrm{Cd}$ in their study on the concentrations of lead $(\mathrm{Pb})$ and cadmium $(\mathrm{Cd})$ residues in frozen chicken vended within Ibadan, Southern part (Lagos and Ibadan) of Nigeria. Similarly, higher levels of $\mathrm{Cu}, \mathrm{Mn}$, and $\mathrm{Pb}$ in fresh and grilled guinea fowl meat was reported from Tamale Metropolis, Ghana (Adzitey et al. 2015). These findings are in line with previous submissions, who attributed the probable differences in the levels of heavy metals contamination to the variations in the levels of exposure and concentration of elemental metals within the tissues of the animal (Iwegbue et al., 2008; Adzitey et al. 2015; Ogu et al., 2017; Mottalib et al., 2018).

With respect to the sampling location, the concentration of each metal studied varied significantly $(\mathrm{P}<0.05)$ as shown in Table 2. Chicken meat samples retailed at Warri main markets (58.9\%) had the highest level of metal contamination, and was followed by Benin City (26.8\%), Ado-Ekiti (10.2\%) and Akure (4.2\%) samples. The variations observed could be due to the differences in the intensity of industrial/commercial activities/wastes generation within and around the study locations. For instances, one of the study locations (Warri), which had the highest level of metal residues in the chicken meat samples, is the hub for generation of petrochemical wastes from petroleum production and auto-mechanic workshops. The implication of this environmental effect was also observed in the study carried out by Kelvin and Lawrence (2015), who reported a substantial higher level of heavy metals contamination in suya meat marketed within Warri metropolis. Apart from Delta State, intense industrial/metallic/metallurgical activities are also prevalent in Benin City, which could be the probable reason for the substantial levels of the tested metals in this study (Ebabhamiegbebho et al., 2018).

Moreover, recent study found that significant levels of Lead (Pb), Chromium (Cr) and Nickel (Ni) in commercial snail meat (Archachatina marginata) consumed within Edo State, suggesting the availability of these heavy metals within Benin City, the capital City of Edo State, Southern Nigeria. Similarly, substantial levels of lead, copper, zinc, cadmium and chromium, were also found in cattle meat from and Ekiti State and Akure, Ondo State (Areoye et al., 2018). Studies have shown that exhaust/effluents from automobiles, burning of fossil fuel, factory chimneys, gas flaring, crude oil production and smelting of ores, among others, are the commons sources of generation 
of environmental heavy metal pollution and food contamination (Tchounwou et al., 2012; Jaishankar et al., 2014; Thompson and Darwish, 2019). 
Table 1: Analysis of the heavy metals' levels ( $\mathrm{mg} / \mathrm{kg}$ ) in chicken meat samples

\begin{tabular}{|c|c|c|c|c|c|c|c|c|}
\hline \multirow{2}{*}{$\begin{array}{l}\text { Heavy } \\
\text { metal }\end{array}$} & \multicolumn{2}{|c|}{ Ado-Ekiti } & \multicolumn{2}{|c|}{ Akure } & \multicolumn{2}{|c|}{ Benin City } & \multicolumn{2}{|c|}{ Warri } \\
\hline & Range & Mean \pm SE & Range & Mean \pm SE & Range & Mean \pm SE & Range & Mean $\pm \mathrm{SE}$ \\
\hline $\mathrm{Pb}$ & $0.061-1.151$ & $0.141 \pm 0.025^{\mathrm{c}}$ & $0.009-0.012$ & $0.010 \pm 0.000^{b}$ & $0.011-0.026$ & $0.023 \pm 0.003^{\mathrm{ab}}$ & $0.111-0.154$ & $0.122 \pm 0.001^{b}$ \\
\hline $\mathrm{Cr}$ & $0.002-0.293$ & $0.078 \pm 0.057^{\mathrm{a}}$ & $0.001-0.005$ & $0.001 \pm 0.001^{\mathrm{a}}$ & $0.034-0.045$ & $0.041 \pm 0.023^{b}$ & $0.056-0.089$ & $0.067 \pm 0.011^{\mathrm{a}}$ \\
\hline $\mathrm{Cd}$ & $0.212-1.007$ & $0.323 \pm 0.022^{\mathrm{d}}$ & $0.010-0.011$ & $0.005 \pm 0.000^{\mathrm{b}}$ & $0.009-0.011$ & $0.010 \pm 0.000^{\mathrm{a}}$ & $0.022-0.045$ & $0.039 \pm 0.012^{\mathrm{a}}$ \\
\hline $\mathrm{Mn}$ & $0.022-0.102$ & $0.100 \pm 0.001^{\mathrm{b}}$ & $0.100-0.210$ & $0.141 \pm 0.011^{\mathrm{d}}$ & $0.098-0.167$ & $0.112 \pm 0.005^{\mathrm{c}}$ & $1.094-1.678$ & $1.206 \pm 0.003^{\mathrm{d}}$ \\
\hline $\mathrm{Ni}$ & $0.040-0.131$ & $0.125 \pm 0.015^{\mathrm{bc}}$ & $0.091-0.113$ & $0.099 \pm 0.002^{\mathrm{cd}}$ & $1.113-1.678$ & $1.203 \pm 0.001^{\mathrm{d}}$ & $1.890-2.072$ & $1.981 \pm 0.002^{\mathrm{e}}$ \\
\hline $\mathrm{Zn}$ & $0.101-0.123$ & $0.117 \pm 0.101^{\mathrm{b}}$ & $0.076-0.102$ & $0.089 \pm 0.013^{\mathrm{cd}}$ & $1.023-2.089$ & $1.101 \pm 0.003^{\mathrm{d}}$ & $1.913-2.782$ & $2.094 \pm 0.001^{\mathrm{e}}$ \\
\hline $\mathrm{Cu}$ & $0.053-0.110$ & $0.104 \pm 0.001^{\mathrm{ab}}$ & $0.011-0.104$ & $0.067 \pm 0.001^{\mathrm{c}}$ & $0.086-0.209$ & $0.104 \pm 0.100^{\mathrm{c}}$ & $0.152-0.213$ & $0.192 \pm 0.120^{c}$ \\
\hline
\end{tabular}

*Columns that carry different superscript letter are significantly different at $\mathrm{P}<0.05$. 
Table 2: Mean values of heavy metals in study area

\begin{tabular}{llcc}
\hline Location & No. of sample & Mean heavy metal $(\mathbf{m g} / \mathbf{k g}) *$ & Percentage \\
\hline Ado-Ekiti & 60 & $0.988 \pm 0.207^{\mathrm{c}}$ & $10.2 \%$ \\
Akure & 60 & $0.412 \pm 0.028^{\mathrm{d}}$ & $4.2 \%$ \\
Warri & 60 & $5.701 \pm 0.150^{\mathrm{a}}$ & $58.9 \%$ \\
Benin City & 60 & $2.594 \pm 0.135^{\mathrm{b}}$ & $26.8 \%$ \\
Total & 240 & $9.695 \pm 0.491$ & $100 \%$ \\
\hline
\end{tabular}

*Mean values that carry different superscript letter are significantly different at $\mathrm{P}<0.05$.

Contamination and accumulation of edible food by heavy metals could pose serious health risk to the public (ElBayomi et al., 2018; Thompson and Darwish, 2019). Our study further evaluated the risk associated with the levels of these heavy metals in chicken meat with a view to estimating the possible health risks in children and adult alike via consumption. The potential risks of exposure of humans to these heavy metals via consumption of contaminated chicken meat involves the determination of the estimated daily intake (EDI), vis-a-vis the carcinogenic and noncarcinogenic effects by using the US EPA model and its threshold values as reported earlier (Ekhator et al., 2017; USEPA, 2018).

The estimated daily intake (EDI) (mg/kg/day), hazard ratio (HR), and hazard index (HI) of the analysis are shown in Table 3. The EDI was generally found to be higher in exposed children (with an average weight of $24 \mathrm{~kg}$ ) than in adults (with an average weight of $70 \mathrm{~kg}$ ). This result is in agreement with the findings of Ekhator et al., (2017), in their study on the EDI for children and adults exposed to toxic metals from street vended foods consumed in MidWestern Nigeria. Also, a similar result was reported from Egypt (El-Wehedy et al., 2018). Among the exposed children, Ado-Ekiti samples possessed the highest EDI values for $\mathrm{Pb}(0.274 \mathrm{mg} / \mathrm{kg} / \mathrm{day}), \mathrm{Cr}(0.151 \mathrm{mg} / \mathrm{kg} / \mathrm{day})$ and $\mathrm{Cd}(0.627 \mathrm{mg} / \mathrm{kg} /$ day $)$. However, for $\mathrm{Ni}, \mathrm{Zn}, \mathrm{Cu}$, the highest EDI values were all found in Warri samples, unlike for Mn, with the highest EDI in Akure samples. A similar trend was also observed for EDI in the adults. On the contrary, the lowest EDI values were found in both children and adults for $\mathrm{Pb}, \mathrm{Cr}$ and $\mathrm{Cd}$ in Akure samples. Generally, the EDI values for each of the metals analysed in this study were lower that the established maximum tolerable daily intakes limits, which were; $3.57 \mathrm{mg} /$ day ( $\mathrm{Pb}), 1 \mathrm{mg} /$ day (Cd), 10-500 mg/day (Cu), $11 \mathrm{mg} /$ day (Mn), 5mg/day (Cr), $40 \mathrm{mg} /$ day (Zn) (Institute of Medicine, 2001; Ihedioha et al., 2014; El-Wehedy et al., 2018). This finding is a reflection of the level of contamination of the meat samples in each location.

Based on the EDI obtained, the risk of non-carcinogenic effects of heavy metal consumption in the meat was determined from the hazard quotient or ratio (HR) and chronic hazard index (HI). The target quotient and hazard index are two veritable tools used in estimating assessing lifetime effect of metal exposures in humans via consumptions. An estimated value of greater than or equal to one (1), suggests adverse health hazard to heavy metal exposures (Kigigha et al., 2018). From Table 3, the HR for all the metals studied did not exceed one (1) in both children and adults, except for the children $\mathrm{HR}$ value for $\mathrm{Cd}$ (1.8170) in Warri location, suggesting a possible health risk in exposed children. Basically, health risk index of one (1) is considered an indication of chronic or severe risk of the metals. In 
this study the HI obtained were all below one (1) except for those samples from Warri, especially for the exposed children $(\mathrm{HI}=2.6)$.

Table 4 shows the incremental lifetime cancer risks. From the study, values of the incremental lifetime cancer risks ranged from $10^{-8}$ to $10^{-3}$, and these values, especially among the children are generally unacceptable. Basically, a standard range of permissible predicted lifetime risks for carcinogens was given as $10^{-6}(1$ in $1,000,000)$ to $10^{-4}(1$ in 10,000$)$ and thus, a chemical for which the risk factor falls below $10^{-6}$ may be eliminated from further consideration as a chemical of concern (Patrick-Iwuanyanwu and Chioma, 2017; USEPA, 2018. These findings were relatively lower that those reported by Darwish et al., (2015) and El-Wehedy et al., (2018). The carcinogenic risk is determined and expressed as a probability of getting down with cancer over a lifetime of about 70 years (Ekhator et al., 2018) and according to International Agency for Research on Cancer, the heavy metals, particularly $\mathrm{As}, \mathrm{Cd}$ and $\mathrm{Pb}$ are categorised as carcinogenic metals. In this study, the highest incremental cancer risk was calculated as $7.2 \times 10^{-3}$. The implication of this figure is that exposure to chicken meat via consumption would result in 72 cancer cases per 10,000 people. The risk of cancer for the individual metal was lower than when combined, and this effect appears not to be substantially different $\left(10^{-4}\right.$ to $\left.10^{-3}\right)$ in all the locations studied. The incremental cancer risks for a period of 70 years appeared to be highest among children and adults from Warri, and lowest among children and adults in Akure.

Table 3: Analysis of estimated daily intake (EDI) (mg/kg/day), hazard ratio (HR), and hazard index (HI)

\begin{tabular}{|c|c|c|c|c|c|c|c|c|c|}
\hline \multirow{2}{*}{\multicolumn{2}{|c|}{$\begin{array}{c}\text { Risk } \\
\text { Assessment }\end{array}$}} & \multicolumn{2}{|c|}{ Ado-Ekiti } & \multicolumn{2}{|c|}{ Akure } & \multicolumn{2}{|c|}{ Benin City } & \multicolumn{2}{|c|}{ Warri } \\
\hline & & Children & Adult & Children & Adult & Children & Adult & Children & Adult \\
\hline \multirow{7}{*}{ EDI } & $\mathrm{Pb}$ & 0.274 & 0.123 & 0.019 & 0.009 & 0.045 & 0.020 & 0.237 & 0.106 \\
\hline & $\mathrm{Cr}$ & 0.151 & 0.068 & 0.002 & 0.001 & 0.080 & 0.036 & 0.130 & 0.058 \\
\hline & $\mathrm{Cd}$ & 0.627 & 0.281 & 0.010 & 0.004 & 0.020 & 0.010 & 0.076 & 0.034 \\
\hline & Mn & 0.194 & 0.087 & 0.274 & 0.123 & 0.217 & 0.098 & 2.341 & 1.050 \\
\hline & $\mathrm{Ni}$ & 0.243 & 0.109 & 0.192 & 0.086 & 2.335 & 1.047 & 3.846 & 1.725 \\
\hline & $\mathrm{Zn}$ & 0.227 & 0.102 & 0.173 & 0.077 & 2.137 & 0.959 & 4.065 & 1.823 \\
\hline & $\mathrm{Cu}$ & 0.202 & 0.091 & 0.130 & 0.058 & 0.202 & 0.091 & 0.373 & 0.167 \\
\hline \multirow{7}{*}{ HR } & $\mathrm{Pb}$ & 0.0684 & 0.0307 & 0.0049 & 0.0022 & 0.0112 & 0.0050 & 0.5921 & 0.0266 \\
\hline & $\mathrm{Cr}$ & 0.0001 & 0.0005 & 0.000001 & 0.00000 & 0.00005 & 0.00002 & 0.00009 & 0.00004 \\
\hline & $\mathrm{Cd}$ & 0.6270 & 0.2812 & 0.0097 & 0.0044 & 0.0194 & 0.0871 & 1.8170 & 0.0340 \\
\hline & $\mathrm{Mn}$ & 0.0097 & 0.0006 & 0.0137 & 0.0009 & 0.0109 & 0.0007 & 0.1171 & 0.0075 \\
\hline & $\mathrm{Ni}$ & 0.0017 & 0.0054 & 0.0014 & 0.0043 & 0.0167 & 0.0524 & 0.0275 & 0.0862 \\
\hline & $\mathrm{Zn}$ & 0.0008 & 0.0003 & 0.0006 & 0.0003 & 0.0071 & 0.0031 & 0.0135 & 0.0061 \\
\hline & $\mathrm{Cu}$ & 0.0050 & 0.0023 & 0.0033 & 0.0015 & 0.0050 & 0.0023 & 0.0093 & 0.0042 \\
\hline \multicolumn{2}{|c|}{$\mathrm{HI}$} & 0.7 & 0.3 & 0.03 & 0.01 & 0.1 & 0.2 & 2.6 & 0.2 \\
\hline
\end{tabular}


Table 4: Incremental lifetime cancer risks of heavy metals on health of adults and children

\begin{tabular}{|c|c|c|c|c|c|c|c|c|c|}
\hline \multirow{2}{*}{\multicolumn{2}{|c|}{$\begin{array}{c}\text { Risk } \\
\text { Assessment }\end{array}$}} & \multicolumn{2}{|c|}{ Ado-Ekiti } & \multicolumn{2}{|c|}{ Akure } & \multicolumn{2}{|c|}{ Benin City } & \multicolumn{2}{|c|}{ Warri } \\
\hline & & Children & Adult & Children & Adult & Children & Adult & Children & Adult \\
\hline \multirow{7}{*}{ ILCR } & $\mathrm{Pb}$ & $2.3 \times 10^{-6}$ & $1.0 \times 10^{-6}$ & $1.6 \times 10^{-7}$ & $7.7 \times 10^{-8}$ & $3.8 \times 10^{-7}$ & $1.7 \times 10^{-7}$ & $2.0 \times 10^{-6}$ & $9.0 \times 10^{-8}$ \\
\hline & $\mathrm{Cr}$ & $7.6 \times 10^{-5}$ & $3.4 \times 10^{-5}$ & $1.0 \times 10^{-6}$ & $5.0 \times 10^{-6}$ & $4.0 \times 10^{-5}$ & $1.8 \times 10^{-5}$ & $6.5 \times 10^{-5}$ & $2.9 \times 10^{-5}$ \\
\hline & $\mathrm{Cd}$ & $2.3 \times 10^{-4}$ & $8.4 \times 10^{-5}$ & $3.8 \times 10^{-6}$ & $1.5 \times 10^{-6}$ & $7.6 \times 10^{-6}$ & $3.8 \times 10^{-6}$ & $2.9 \times 10^{-5}$ & $1.3 \times 10^{-5}$ \\
\hline & $\mathrm{Mn}$ & ND & ND & ND & ND & ND & ND & ND & ND \\
\hline & $\mathrm{Ni}$ & $4.1 \times 10^{-4}$ & $1.9 \times 10^{-4}$ & $3.3 \times 10^{-4}$ & $1.5 \times 10^{-4}$ & $4.0 \times 10^{-3}$ & $1.8 \times 10^{-3}$ & $6.5 \times 10^{-3}$ & $2.9 \times 10^{-3}$ \\
\hline & $\mathrm{Zn}$ & ND & ND & ND & ND & ND & ND & ND & ND \\
\hline & $\mathrm{Cu}$ & $3.0 \times 10^{-4}$ & $1.4 \times 10^{-4}$ & $2.0 \times 10^{-4}$ & $8.7 \times 10^{-5}$ & $3.3 \times 10^{-4}$ & $1.4 \times 10^{-4}$ & $5.6 \times 10^{-4}$ & $2.5 \times 10^{-4}$ \\
\hline \multicolumn{2}{|c|}{$\sum$ ILCR } & $1.0 \times 10^{-3}$ & $4.5 \times 10^{-4}$ & $5.3 \times 10^{-4}$ & $2.4 \times 10^{-4}$ & $7.6 \times 10^{-4}$ & $2.0 \times 10^{-3}$ & $7.2 \times 10^{-3}$ & $3.2 \times 10^{-3}$ \\
\hline
\end{tabular}

Importantly, the possible adverse effect associated with some of the heavy metals have been widely reported, despite the fact that some of the heavy metals studied, particularly $\mathrm{Cu}, \mathrm{Zn}$ and $\mathrm{Mn}$ at appropriate levels are essential for normal physiological activities of the system (Ogu et al., 2017). But at elevated levels, $\mathrm{Cu}$ can result in anaemia, hepatotoxicity, renal failure and gastrointestinal disorders, $\mathrm{Zn}$ causes gastro-intestinal disturbances such as nausea, abdominal cramp, vomiting and diarrhoea, while Mn affects the central nervous system leading to permanent disability in exposed children (Tchounwou et al., 2012; Thirulogachandar et al., 2014). The health risk associated with the exposure to $\mathrm{Pb}, \mathrm{Ni}, \mathrm{Cr}$ and $\mathrm{Cd}$ are worrisome because even at trace amounts, they have been found to be exert cytotoxic, mutagenic and carcinogenic effects to major tissues and organs of the body especially in exposed children (Tchounwou, et al., 2012). Though, raw chicken meat are not usually consumed raw, but boiled, roasted or fried in most countries, the presence of these metals in the raw chicken meat samples is, therefore, of public health importance considering the fact that previous studies found that cooked meat had higher metal residues vis-a-vis higher health risks, than the in the raw form (El-Wehedy et al., 2018; Ekhiator et al., 2018).

\section{CONCLUSION}

This study has shown that the relatively essential $(\mathrm{Cu}, \mathrm{Zn}, \mathrm{Mn})$ and non-essential $(\mathrm{Pb}, \mathrm{Cd}, \mathrm{Cr}, \mathrm{Ni})$ heavy metals are present in raw chicken meat retailed with major open markets in southern Nigeria. Interestingly, the determined heavy metals were lower that the established international maximum tolerable daily intakes limits. The non-carcinogenic risks $(\mathrm{HR} / \mathrm{HI})$ associated with the metals in each location were substantially low for the metals studied in all the locations except for $\mathrm{Cd}$, which could pose serious health risk among children in one of the locations. Similarly, the incremental cancer risk posed by these metal ranges from $10^{-4}$ to $10^{-3}$ in all the locations, suggesting at least a cancer case per 10,000 exposed people (both in children and adults). The incremental cancer risks for a period of 70 years are highest more among children and adults from Warri, and lowest among children and adults in Akure. Considering the fact that previous studies have revealed that cooking/thermal processing of meat probably increases the public health risks of heavy metals, it is therefore pertinent to suggest that proper identification of the critical control hazards points of heavy metals along meat production chains so as to drastically reduce the risk posed by these heavy metals via consumption. 


\section{REFERENCES}

Abdel-Rahman, G. N., Ahmed, M. B. M. and Marrez, D. A. (2018). Reduction of heavy metals content in contaminated vegetables due to the post-harvest treatments. Egyptian Journal of Chemistry. 61(6):10311037.

Adedokun, A. H., Njoku, K. L., Akinola, M. O., Adesuyi, A. A. and Jolaoso, A. O. (2016). Potential human health risk assessment of heavy metals intake via consumption of some leafy vegetables obtained from four market in Lagos Metropolis, Nigeria. Journal of Applied Sciences and Environmental Management. 20 (3): 530-539.

Adzitey, F., Kumah, A. and Mensah, S. B. K. (2015). Assessment of the presence of selected heavy metals and their concentration levels in fresh and grilled beef/guinea fowl meat in the Tamale Metropolis, Ghana. Research Journal of Environmental Sciences. 9: 152- 158. doi: 10.3923/rjes.2015.152.158.

Areoye, A. G., Areoye, J. O. and Omoleye, O.S. (2018). Assessment of selected heavy metal residues in meat of cattle in Ondo State, Nigeria. Elixir Agriculture. 123: 52063-52068.

Benouadah, A., Diafat, A. and Djellout, B. (2015). Assessment of trace heavy metals contents of chicken from Algeria. International Journal of Plant, Animal and Environmental Sciences. 5(2): 45- 50.

Darwish, W. S., Hussein, M. A., El-Desoky, K.I., Ikenaka, Y., Nakayama, S., Misukawa, H. and Ishizuka, M. (2015). Incidence and public health risk assessment of toxic metal residues (cadmium and lead) in Egyptian cattle and sheep meats. International Food Research Journal. 22: 1719-1726.

Ebabhamiegbebho, P. A., Igene, J. O., Izebhoa O., Evivie, S. E. and Abel, E. S. (2018). Some heavy metals concentration in raw and smoke-dried snail (Archachatina marginata) meat consumed in Edo State, Nigeria. Biological and Environmental Sciences Journal for the Tropics. 15(2): 28-35.

Ekhator, O. C., Udowelle, N. A., Igbiri, S. Asomugha, R. N. Igweze, Z. N. and Orisakwe, O. E. (2017). Safety evaluation of potential toxic metals exposure from street foods consumed in mid-west Nigeria. Journal of Environmental and Public Health. 2017. e8458057, 8 pages https://doi.org/10.1155/2017/8458057.

Elalfy, M. M., Zakaria, A. I. and Elsayed, M. M. (2018). Association of cadmium, lead, mercury and zinc occurrence in bovine meat with artesian water pollution in Dakahlia Governorate Egypt with the comparison to imported Bovine Meat. EC Veterinary Science. 3: 355-359.

El-Bayomi, R. M., Darwish, W. S., Elshahat, S. S.M. and Hafez, A. E. (2018). Human health risk assessment of heavy metals and trace elements residues in poultry meat retailed in Sharkia Governorate, Egypt. Slovenian Veterinary Research. 55 (Suppl. 20): 211-219. doi: 10.26873/svr-647-2018.

El-Wehedy, S. E., Darwish, W. S., Tharwat, A.E. and Hafez, A. E. (2018). Estimation and health risk assessment of toxic metals and antibiotic residues in meats served atHospitals in Egyptian. Journal of Veterinary Science and Technology. 9: 524. doi:10.4172/2157-7579.1000524.

Gayawan, E., Arogundade, E. D. and Adebayo, S. B. (2014). Possible determinants and spatial patterns of anaemia among young children in Nigeria: a Bayesian semi-parametricmodelling. International Health. 6:35-45.

Haleelu, M. M., Yahiya, S. and Gwarzo, DA (2015). Assessment of heavy metals in someorgans of local chickens 
sold at central market of Wudil Metropolis. International Journal of Resent Trends in Science \& Technology. 2 (9): 3226-3231.

Hu, W., Wang, H., Dong, L., Huang, B., Borggaard, O. K., Bruun, H. C., He, Y., Holm, P. E. ～(2018). Source identification of heavy metals in peri-urban agricultural soils of southeast China: an integrated approach. Environnemental Pollution. 237 : 650-661. doi: 10.1016/j.envpol.2018.02.070.

Ihedioha, J. N., Okoye, C. O. B. and Onyechi, C. A. (2014). Health risk assessment of zinc, chromium, and nickel from cow meat consumption in an urban Nigerian population. International Journal of Occupational and Environmental Health. 20 (4): 281-288.

Institute of Medicine (2001). Dietary Reference Intakes for Vitamin A, Vitamin K, Arsenic, Boron, Chromium, Copper, Iodine, Iron, Manganese, Molybdenum, Nickel, Silicon, Vanadium, and Zinc. Washington, DC: The National Academies Press.

Issa, A. B., Yasin, K., Loutfy, N. and Ahmed, M. T. (2018). Risk assessment of heavy metals associated with food consumption in Egypt: A pilot study. Journal of Clinical and Experimental Toxicology. 2(1):10-19.

Iwegbue, C. M. A., Nwajei, G. E. and Iyoha, E. H. (2008). Heavy metal residues of chicken meat and gizzard and turkey meat consumed in southern Nigeria. Bulgarian Journal of Veterinary Medicine. 11(4):275-280.

Jaishankar, M., Tseten, T., Anbalagan, N., Mathew, B. B. and Beeregowda, K. N. (2014) Toxicity, mechanism and health effects of some heavy metals. Interdisciplinary Toxicology. 7(2): 60-72. doi: 10.2478/intox-20140009.

Järup, L. (2003). Hazards of heavy metal contamination. British Medical Bulletin. 68(1): 167-182. https://doi.org/10.1093/bmb/ldg032

Javadi, A. and Safarmashaei, S. (2011). Microbial profile of marketed broiler meat. Middle. East Journal of Scientific Research. 9(5): 652-656.

Kelvin, O. C. and Lawrence, E. O. (2015). Heavy metals contamination levels in suya meat marketed in selected towns in Delta State, Nigeria. IOSR Journal of Environmental Science, Toxicology and Food Technology. 9 (11): 110-113.

Kigigha, L. T., Nyenke, P. and Izah, S. C. (2018). Health risk assessment of selected heavy metals in gari (cassava flake) sold in some major markets in Yenagoa metropolis, Nigeria. MOJ Toxicology. 4(2):47-52. doi: 10.15406/mojt.2018.04.00089.

Kim, H. T., Loftus, J. P., Mann, S. and Wakshlag, J. J. (2018). Evaluation of Arsenic, Cadmium, Lead and Mercury contamination in over-the-counter available dry dog foods with different animal ingredients (red meat, poultry, and fish). Frontiers in Veterinary Science.5:

264. https://doi.org/10.3389/fvets.2018.00264.

Makanjuola, O. M. (2016). Assessment of heavy metal in raw meat sold in some notable garages in Ogun State, South West, Nigeria. International Journal of Research Studies in Biosciences (IJRSB). 4 (9): 10-13. http://dx.doi.org/10.20431/2349-0365.0409003.

Mottalib, M. A., Zilani, G., Suman, T. I., Ahmed, T. and Islam, S. (2018). Assessment of Trace Metals in 
Consumer Chickens in Bangladesh. Journal of Health \& Pollution. 8(20):181208. doi: 10.5696/2156-96148.20.181208.

Oforka, N. C., Osuji, L. C. and Onwuachu, U. I. (2012). Estimation of dietary intake of cadmium, lead, manganese, zinc and nickel due to consumption of chicken meat by inhabitants of Port-Harcourt Metropolis, Nigeria. Archives of Applied Science Research. 4(1): 675-684.

Ogu, G. I. and Akinibosun, F. I. (2019). Occurrence of Salmonella in raw chicken meat from retail equipment and environments in Southern Nigeria Open Markets. Notulae Scientia Biologicae, 11(2):175-182. https://doi.org/10.15835/nsb11210469.

Ogu, G. I., Madar, I. H., Okolo, J. C., Eze, E. M., Srinivasan, S. and Tayubi, I. A. (2017) Exposure assessmentof chicken meat to heavy metals and bacterial contaminations in Warri Metropolis, Nigeria. International Journal of Scientific Innovations. 1 (1): 07-14.

Olusola, A. V., Diana, B. E. and Ayoade, O. I. (2012) Assessment of tetracycline, Lead and cadmium residues in frozen chicken vended in Ibadan, Oyo State, Nigeria. Pakistan Journal of Biological Sciences. 15 (17): 833844.

Odoh, R., Ogah, E. and Ushie, O. A. (2016). Determination of some heavy metal profiles in supported by meat of domesticated animals in the vicinity of Kaduna south industrial area, Nigeria. FUW Trends in Science \& Technology Journal. 1(2): 337 - 343

Patrick-Iwuanyanwu, K. and Chioma, N. C. (2017). Evaluation of Heavy Metals Content and Human Health Risk Assessment via Consumption of Vegetables from Selected Markets in Bayelsa State, Nigeria. Biochemistry and Analytical Biochemistry. 6: 332. doi: 10.4172/21611009.1000332

Salazar-Flores, J., Torres-Jasso, J. H., Rojas-Bravo, D., Reyna-Villela, Z. M., TorresSánchez, E. D. (2019). Effects of Mercury, Lead, Arsenic and Zinc to Human Renal Oxidative Stress and Functions: A Review. Journal of Heavy Metal Toxicity and Diseases. 4(1):2. doi:10.21767/2473-6457.10027.

Shaheen, N., Irfan, N. M., Khan, I. N., Islam, S., Islam, M. S., Ahmed, M. K. (2016). Presence of heavy metals in fruits and vegetables: health risk implications in Bangladesh. Chemosphere. 152: 431-438.

Suruchi and Pankaj Khanna (2011). Assessment of Heavy Metal Contamination in Different Vegetables Grown in and Around Urban Areas. Research Journal of Environmental Toxicology. 5:162179. doi: $10.3923 /$ rjet.2011.162.179

Tchounwou, P. B., Yedjou, C. G., Patlolla, A. K. and Sutton, D. J. (2012). Heavy metals toxicity and the environment. EXS. 101: 133-164.

Thirulogachandar, M. E., Rajeswari, M. and Ramya, S. (2014). Assessment of heavy metals in Gallus and their impacts on Human. International Journals of Scientific Research Publications. 4 (6): 1-8.

Thompson, L. A. and Darwish, W. S. (2019). Environmental Chemical Contaminants in Food: Review of a Global Problem. Journal of Toxicology Volume 2019, Article ID 2345283, $14 \quad$ pages https://doi.org/10.1155/2019/2345283.

USEPA (2018). United States Environmental Protection Agency Regional screening levels (RSLs)-generic 
tables. Washington, D.C.: 2018. Accessed on the November 17, 2018 from:

https://www.epa.gov/risk/regional-screening-levels-rsls-generic-tables.

Wang, R., Zhong, B., Pi, L., Xie, F., Chen, M., Ding, S., Su, S., Li, Z. and Gan, Z. (2018). Concentrations and exposure evaluation of metals in diverse food items from Chengdu, China. Archives of Environmental Contamination and Toxicology. 74(1):131 139. https://doi. org/10.1007/s00244-017-0420-y. 